\title{
The Future of Benthic Indicators: Moving up to the Intertidal
}

\author{
Nicolas Spilmont ${ }^{1,2,3}$ \\ ${ }^{1}$ University Lille Nord de France, Université Lille 1 Sciences et Technologies, \\ Laboratoire d'Océanologie et Géosciences (LOG), Wimereux, France \\ ${ }^{2}$ CNRS, UMR 8187 Laboratoire d'Océanologie et Géosciences (LOG), Wimereux, France \\ ${ }^{3}$ Environmental Futures Centre, Griffith University, Gold Coast Campus, Australia \\ Email: nicolas.spilmont@univ-lille1.fr
}

Received April 19, 2013; revised May 21, 2013; accepted June 2, 2013

Copyright (C) 2013 Nicolas Spilmont. This is an open access article distributed under the Creative Commons Attribution License, which permits unrestricted use, distribution, and reproduction in any medium, provided the original work is properly cited.

\begin{abstract}
The use of benthic indicators has increased dramatically during the last decades. The number of articles published on the subject, as well as the number of citations, has been particularly increasing since the early 90 's, notably in relation with the implementation of directives for the management of aquatic/marine ecosystems such as the Water Framework Directive and the Marine Strategy Framework Directive. Current benthic indicators suffer from severe drawbacks and their practical use is still discussed and might have reached a dead end. Indicators based on species composition are not totally satisfactory, mainly because they exhibit a high spatio-temporal variability (e.g. variable at both seasonal and pluri-annual scales) and are user-dependent (e.g. divergent results from US or Europe experts.) In turn, modifications of behaviour, metabolism, phenotype or stable isotopes composition in invertebrates usually occur at short time scales, compared to detectable changes in community composition, and makes their use particularly relevant as indicators of perturbation. It is argued in this paper that these functional indicators might be relatively quickly implemented in the intertidal, and represent an effective alternative to current benthic indicators.
\end{abstract}

Keywords: Benthic Indicators; Intertidal; Ecosystem Functioning; Anthropogenic Disturbance; Global Change

\section{Introduction}

Global climate change is now unequivocal [1,2], and publications on the topic are legion; see e.g. [3,4] for reviews. Coastal ecosystems are increasingly threatened by the combined effects of global warming and its direct and indirect consequences (e.g. erosion and sea level rise) and other major anthropogenic pressures (including habitat change, invasive species, eutrophication, chemical pollution, overexploitation [5]), which justify the development of ecological indicators to evaluate their health (see [6] for a review). The concept of indicators in aquatic ecology and ecosystem management is not recent and indicators are now considered as "mainstream tools" in assessing the quality of aquatic ecosystems [7]. Their use has increased dramatically during the last few decades [8,9], notably in relation with the implementation of international directions for the management of aquatic/ marine ecosystems such as the Water Framework Directive (WFD, 2000/60/EC) and the Marine Strategy Framework Directive (MSFD, 2008/56/EC) in Europe (see e.g. [10]). In this context, due to their sedentarily and long life span, benthic organisms are considered as good integrators of environmental changes in marine ecosystems and have been extensively used as indicators for ecosystem changes (e.g. $[9,11,12])$. The practical use of current benthic indicators in marine ecosystems is, however, still fiercely discussed (e.g. [6]). In this paper, after a short review and bibliometric survey, I will stress how the study of intertidal ecosystems could help to implement new indicators that would, in tidal seas, complete, if not replace, current benthic indicators.

\section{Benthic Indicators: Where Are We?}

Benthic indicators (see e.g. [13,14] for definitions) are a particularly popular topic in marine sciences; the ISI Web Of Science (accessed April 10, 2013 for the combination "benthic indices or benthic indicator* and marine") returned 3306 papers published and 54,282 citations between 1967 and 2012. Papers dealing with benthic indicators are amongst the ten most cited papers in special- 
ized journals such as Marine Pollution Bulletin ([15] and [16] with 363 and 272 citations, respectively) and Ecological Indicators ([17-20] with 69, 70, 89 and 93 citations, respectively.) The number of articles published on the subject, as well as the number of citations, has been drastically increasing since the early 90's (Figure 1).

The related mean annual growth rate [21,22] for the period 1991-2012 has subsequently been estimated from the slope $\alpha$ of the semi logarithmic plot of the number of articles published $v$ s. time as $12.4 \%$ (Figure 2).

It is, however, well known that the growth rate of scientific publication is almost constantly raising [21,22]. Therefore, data from the ISI Web Of Science were also collected for all published papers and for papers published in marine sciences only (i.e. records containing "marine") for the period 1991-2012 (Figure 2). Using the approach described above, the mean annual growth rate for all fields combined was $4.1 \%$ and $7.0 \%$ for marine sciences specifically, both being significantly lower than the $12.4 \%$ for benthic indicators (t-test for slope comparison, $p<0.05$.) Note that the sharp increase observed in the early 90's is also seen for marine sciences, but not for the overall outputs from the Web of Science. This feature was previously detected for several fields in ecology [23], for example for studies related to coastal biogeochemistry [24], pollution in estuaries [25] and

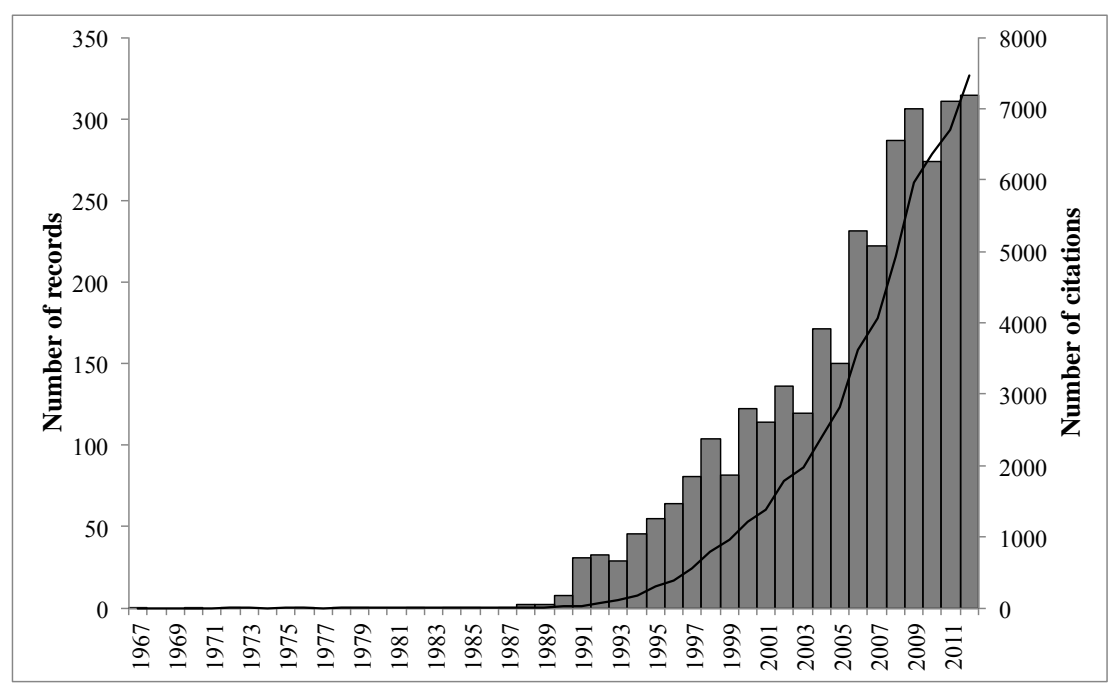

Figure 1. Number of publications (bars) and number of citations (solid line) in the field of marine benthic indicators (i.e. for the keywords combination "benthic indices or benthic indicator* and marine") recovered from the ISI Web of Knowledge database (accessed early March 2013) for the period 1967 (first reference in the field)-2012.

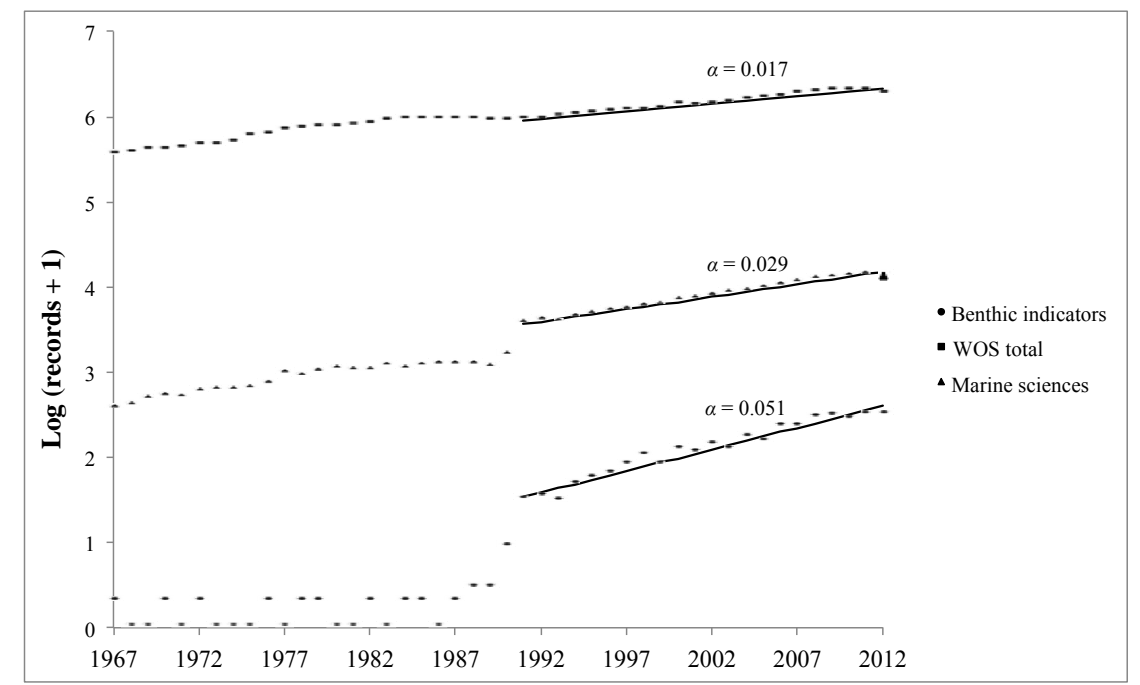

Figure 2. Number of records in the ISI Web of Science database (accessed early March 2013, semi logarithmic scale) for marine benthic indicators (i.e. for the keywords combination "benthic indices or benthic indicator* and marine", circles), marine sciences (i.e. for the keyword "marine", triangles) and total number of records in the database (squares). The slopes $\alpha$ from the linear regressions are given for the period 1991-2012. 
eutrophication [26]. Interestingly enough, there is no significant change in the slope (summed cumulated function method [27]), hence in the growth rate, of publications on marine benthic indicators in the 2000's. This suggests that the vote and implementation of both the WFD (2000) and MSFD (2008) did not have any significant impact on the publication efforts, though more than 300 new methods were described for the WFD [9].

Due to the variety of existing benthic indicators, most of the recent papers aimed to compare their efficiency using different sampling methods (sampler and mesh size [28]), taxonomic levels [29,30], or testing experts from USA and Europe [31]. Numerous studies also compared the consistency of different indicators for evaluating the ecological status of a selected area [11,12,20,32-41]. Overall, these comparisons revealed inconsistencies between indicator responses, some sampling stations being classified either in a "poor" or "high" ecological status depending on the index used [32], or samples considered as either "unaffected" or "severely affected" depending on the expert $[12,31]$. This short review demonstrates, as recently stressed [6], that current benthic indicators suffer from severe drawbacks (Table 1) and do not fulfil the requirements for being "good indicators" sensu [42]. Most of them are usually specific to a habitat or geo- graphical area (for a review see e.g. [20]) and highly variable at both seasonal $[43,44]$ and pluri-annual scales [45]. Most authors usually agree on, for example, the general efficiency of the AMBI and the derived MAMBI $[34,37,40,41,46,47]$ or the relative ineffectiveness of the BOPA index $[32,48,49]$. However, the practical use of benthic indicators might have reach a dead end, since no real consensus has been reached yet and inter-calibration and standardisation are still needed, as shown by the ongoing inundation of papers related to comparesons or intercalibrations (see references here above).

Recently, indices have been developed (or revised) based on other benthic groups than macrofauna, such as macroalgae either alone $[52,53]$ or combined with macrofauna [54], and meiofauna, including nematods [55] and foraminifera [56,57]. These indices however share disadvantages with macofauna-based indices, such as the requirement of a high degree of specialisation (particularly for some meiofaunal groups such as nematods [58]), and contribute to the current indicator inundation that sometimes leads to awkward situations when the indice values are much more difficult to determine than the environmental factor it is supposed to be representative of (e.g. living foraminifera assemblages diversity as an in

Table 1. Selected examples of the main drawbacks of current benthic indicators.

\begin{tabular}{|c|c|c|}
\hline Drawback & Example & Reference \\
\hline \multirow{2}{*}{ Expert dependence } & $\begin{array}{l}\text { Major differences in the ecological classification for } 7 \% \text { of the samples } \\
\text { examined by expert from France and Algeria }\end{array}$ & {$[12]$} \\
\hline & $\begin{array}{l}\text { Major differences in the ecological classification for } 58 \% \text { of the samples } \\
\text { examined by expert from Europe and USA }\end{array}$ & {$[31]$} \\
\hline \multirow{2}{*}{ Methodological dependence } & $\begin{array}{l}\text { Major differences in the ecological classification for } 28 \% \text { to } 48 \% \text { of the sta- } \\
\text { tions analysed, depending on the sieving method }(0.5 \mathrm{~mm} \text { vs. } 1 \mathrm{~mm} \text { mesh } \\
\text { size, tested on } 3 \text { different indicators })\end{array}$ & {$[20]$} \\
\hline & $\begin{array}{l}\text { Major differences in the ecological classification for } 17 \% \text { to } 83 \% \text { of the } \\
\text { stations analysed, depending on the sampling method (Van Veen grab vs. } \\
\text { corere, tested on } 7 \text { different indicators) }\end{array}$ & {$[28]$} \\
\hline \multirow{3}{*}{$\begin{array}{l}\text { Inconsistency between } \\
\text { indicators }\end{array}$} & $\begin{array}{l}\text { Five different biotic indices disagreed on the status of } 65 \% \text { to } 90 \% \text { of the sta- } \\
\text { tions sampled in semi-ecnlosed systems and transitional waters }\end{array}$ & {$[33]$} \\
\hline & $\begin{array}{l}\text { Dissimilarity of the ecological status obtained by } 6 \text { indices varied from } 3 \% \text { to } \\
64 \% \text { (stations sampled in coastal and lagoon locations) }\end{array}$ & {$[32]$} \\
\hline & $\begin{array}{l}\text { Major differences in the ecological classification for } 74 \% \text { of the stations } \\
\text { examined depending on the indicator used ( } 3 \text { tested) }\end{array}$ & {$[37]$} \\
\hline \multirow{3}{*}{ Temporal variability } & $\begin{array}{l}\text { Major differences in the ecological classification of a single sampling station } \\
\text { along a pluri-annual survey (using the M-AMBI and BENTIX indices) }\end{array}$ & {$[37]$} \\
\hline & $\begin{array}{l}\text { Major differences in the ecological classification of } 3 \text { sampling stations at the } \\
\text { seasonal scale ( } 5 \text { indices tested) }\end{array}$ & [43] \\
\hline & $\begin{array}{l}\text { Major differences in the ecological classification of a single sampling station } \\
\text { along a long-term ( } 30 \text { year) survey ( } 6 \text { indicators tested) }\end{array}$ & {$[45]$} \\
\hline \multirow{2}{*}{ Operational limits } & $\begin{array}{l}\text { Five digits for the BOPA index (e.g. } 0.04576<\text { BOPA }<0.13966 \text { and } 0.13966 \\
<\text { BOPA }<0.19382 \text { for a good and moderate ecological status, respectively) }\end{array}$ & {$[50]$} \\
\hline & $\begin{array}{l}\text { Five digits for the } \mathrm{BO} 2 \mathrm{~A} \text { index }(\text { e.g. } 0.01951<\mathrm{BO} 2 \mathrm{~A}<0.13100 \text { and } 0.13101 \\
<\mathrm{BO} 2 \mathrm{~A}<0.19804 \text { for a good and moderate ecological status, respectively) }\end{array}$ & {$[51]$} \\
\hline
\end{tabular}


dicator of dissolved $\mathrm{O}_{2}$ concentration [56].) Besides, the claim that indicators' outputs and interpretation should be understood by non-scientists [38,59] (see however [60] for criticisms), leads to a jargon where some terms do not have any ecological reality anymore (this is the case for the widely used "reference state" $[6,61]$ ) or have different meanings in a management and a purely ecological context, such as "ecosystem" [62,63], which also contributes to the general confusion.

\section{Where to Go Next?}

As stated above, benthic indicators based on species composition are not totally satisfactory as communities can be disrupted but exhibit only minor changes in their composition (e.g. [64]). In turn, phenotypic and metabolic changes can be observed in impacted areas, even if the community structure (e.g. abundance, diversity) remains unchanged. Behavioural, metabolic, phenotypic and stable isotopes composition modifications in invertebrates usually occur at short time scales [4], compared to detectable changes in community composition (except in the extreme case of catastrophic events such as oil spills) and thus makes their use particularly relevant as indicators of perturbation. Regarding for example behavioural analysis, they have previously been underlined as "early warning" signals to assess the status of marine environments [65].

Most of the highest predicted cumulated impacts of humans on marine ecosystems are in areas of continental shelf and slopes, including hard and soft continental shelves and rocky reefs [5]. Ecosystem modifications in response to these changes include extinctions, changes in food web structures and shifts in geographical distribu- tion of species [1]. In the latter case, intertidal organisms are considered as being potential harbingers of climatedriven changes in distribution patterns [66] because most of them live very close to their thermal tolerance limits $[67,68]$. Furthermore, intertidal areas are home to some of the highest rates of primary production in the world [69] and their status (sink/source) regarding the $\mathrm{CO}_{2}$ global cycle is still uncertain [70]. Understanding their role in the global carbon cycle is, however, of primary importance since the efficiency of the global ocean carbon pump is expected to decrease [1,71] and about $40 \%$ of the carbon sequestration in the oceans occur along continental margins [72]. Thus, intertidal areas do not only occupy a keystone ecological position as a land/sea and air/water interface but also represent a compartment of primary importance to assess the impact of human activities and global warming on marine ecosystems [67]. Intertidal ecology is a productive field in marine sciences, as seen from the constant increase in published works on the intertidal environment since the early 90's (Figure 3).

Note that the related growth rate $(5.7 \%)$, though significantly lower than the ones for benthic indicators and marine sciences, corresponds to a significantly more pronounced increase than the one observed in general sciences. One of the main advantages of the intertidal environment is its accessibility and the subsequent relative ease to observe the distribution and behaviour of organisms, and to perform manipulative experiments. This is particularly true for rocky shores that have been extensively used to study species interactions relatively early (60's and 70's), notably with the work of Connell [73], Paine [74] and Underwood [75]. Note that the re-

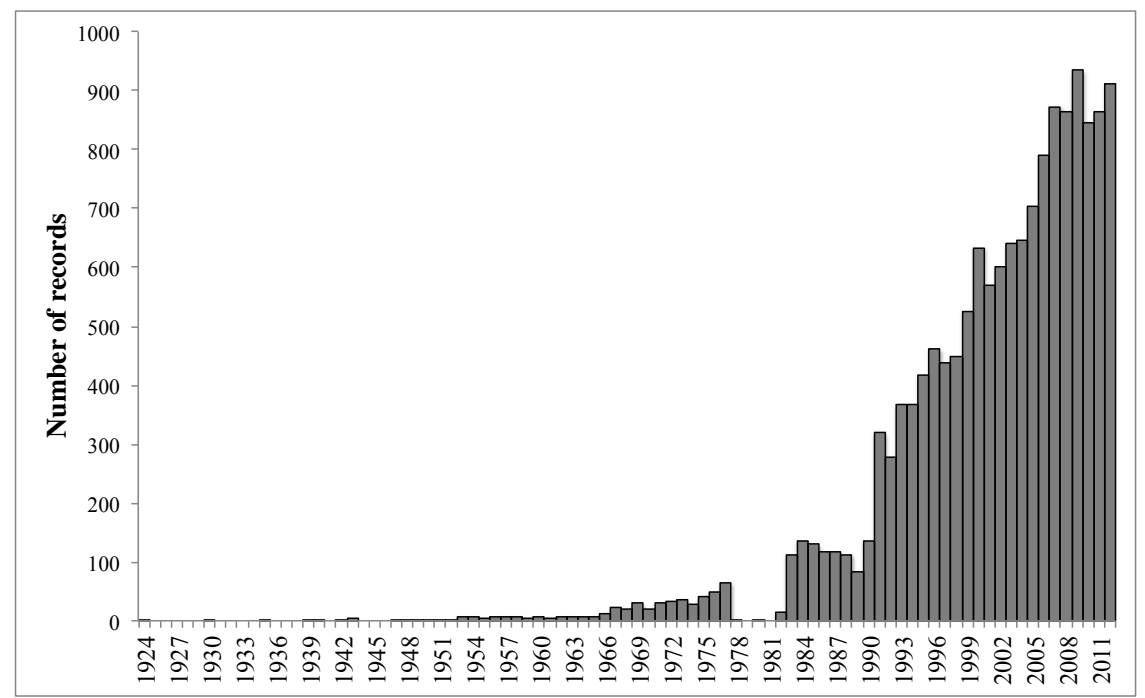

Figure 3. Number of publications in the field of intertidal ecology (i.e. for the keywords combination "intercotidal or intertidal”) recovered from the ISI Web of Knowledge database (accessed early March 2013) for the period 1924 (first reference in the field)-2012. 
vival of interest in intertidal ecology in the early 80 's (Figure 3) matches with the first papers published on the primary production of microphytobenthos [76]. Ever since, soft sediment functioning has been continuously and increasingly studied, especially in areas where both human uses and impacts are manifest, i.e. estuaries (mudflats) and sandy shores (beaches.)

In this framework, the intertidal represents an ideal candidate for the development of new indicators and studies concerning the impact of anthropogenic (direct and indirect) disturbances on the functioning of intertidal systems have been multiplying during the last decade. Modifications in the behaviour, phenotype, metabolism or isotopic composition of intertidal invertebrates might be useful to detect non-natural changes in relation with e.g. alien species introduction [77,78], topographic modifications [79], the presence of plastic litter [80], metal contamination in sediment [81], exposition to pesticides $[82,83]$, acidification $[84,85]$ and temperature increase [86-88]. Furthermore, tools usually used to trace organic matter in the trophic network (i.e. stable isotopes and fatty acids) have also been used as indicators for environmental changes [89-91]. The monitoring of $\mathrm{CO}_{2}$ fluxes at the air/sediment interface also appears to be particularly interesting since they are mainly dependent on variations in light and temperature at several scales $[92,93]$, and have been shown to respond to direct and indirect consequences of global change. This includes climatic events (exceptional warm year [70]), micro- and macro-algal deposits in soft sediments [94-97], canopy loss on rocky shores [98], and most probably acidification [99].

Potential benthic indicators are thus numerous in the intertidal. However, the functioning of intertidal areas is known to be particularly complex, hence the difficulties in the estimation of the impact of climate change [66, 100]. Indeed, the interface position leads to sharp variations in the physical and chemical properties of the environment between immersion and emersion conditions, and the understanding of the impact of environmental stress is made particularly difficult due to theirspatiotemporal coincidence [101,102]. In addition, the sources of organic matter are numerous [103], leading to often challenging studies on trophic interactions and energy flows [104]. Therefore, a proper knowledge of the functioning of the main intertidal habitats (rocky shores, sandflats, mudflats, seagrass meadows) is required as a prerequisite to develop a baseline, or "relative reference state" [61]. This would require, beside usual laboratory experiments, long-term surveys and extensive field investigations. Long-term monitoring of $\mathrm{CO}_{2}$ exchanges through automated measurements could be performed using the non-invasive eddy correlation technique which provides direct and continuous measurements of net $\mathrm{CO}_{2}$ exchange at time scales ranging from hours to years [105], integrates large spatial scales, and has been proven efficient in intertidal areas [106]. This method represents a promising tool for large-scale estimations of $\mathrm{CO}_{2}$ fluxes, but techniques such as benthic chambers are more amenable for the detection of fine processes. The situation is much more complicated for long-term, spatially extended, surveys of species distribution in relation with e.g. microhabitats or the collection of individuals for morphometric analysis. This kind of surveys requires important associated manpower and financial resources. It is nowadays recognise that projects that seek to collect field data on large geographical areas and/or over long time periods can only succeed with the help of 'citizen scientists' $[107,108]$. The intertidal being easily accessible and usually frequented by tourists or recurrent users, the help of volunteers can be relatively easily implemented. For example, citizen science has previously been successfully used to assess the presence of invasive crabs in the intertidal zone along more than $1000 \mathrm{~km}$ of coast in the USA [109]. Though usually based on structural factors (presence/richness of some species), citizen science could also be powerful for functional factors with the development of specific protocols and a minimum of training.

\section{Conclusion: Are Science and Policy Compatible?}

It is suggested here that new benthic indicators are needed and should be developed based on the functioning of the ecosystem rather than on community composition. In tidal seas, due to their key interface position, easy access, and coast effectiveness compared to the subtidal [101], intertidal areas offer a great opportunity to quickly develop such indicators. The first step will be to fill potential current knowledge gaps to clearly identify targets (species behaviour, composition, fluxes) and implement protocols that will be unambiguously understandable, hence usable by research consultancies and citizen scientists. There are, however, contradictory interests between science and management policies [59]. Some of the statements advocated here are usually fiercely argued against when discussed with colleagues involved in management e.g. "why have benthic indicators reached a dead end? There are many publications, some introducing new ways for indicator development", "there are plenty of publications showing the ability of current indicators to detect pressure gradients", "there are plenty of papers showing that benthic indicators are indicating effects to marine communities, as required by legislation", or "legislation requires assessing the effects at the community or ecosystem level and legislation deal with managed pressure". These quotations testify that legisla- 
tion leads to 1) a profusion of publications related to benthic indicators that, though probably helpful for the bibliometric profile of some scientists, do not bring any definitive solution (outputs vs. outcomes [59]), 2) ignores the evolution of scientific knowledge that should be included in new management directives and 3) ignores exogenic unmanaged pressures. Elliott [59] recently adressed these problems and stressed that both exogenic unmanaged pressures and endogenic managed pressures should both be tackled in a multidisciplinary approach, and that the 'health' of the system should be considered at six different biological levels (cell, tissue, individual, population, community and ecosystem) $\cdots$ I further suggest "in the intertidal"!

\section{Acknowledgements}

I am grateful to L. Barillé, J.-C. Dauvin, D. Davoult, S. Lefebvre, L. Seuront and D.T. Welsh for their insightful comments on my French HDR Thesis, which contained most of the ideas that were developed in the present work. Thanks are also due to the guest editor for helpful comments, to C. Luczak for fruitful discussions and to an anonymous referee for comments on an early version of this manuscript.

\section{REFERENCES}

[1] M. L. Parry, O. F. Canziani, J. P. Palutikof, P. J. van der Linden and C. E. Hanson, "Climate Change 2007: Impacts, Adaptation and Vulnerability. Contribution of Working Group II to the Fourth Assessment Report of the Intergovernmental Panel on Climate Change," Cambridge University Press, Cambridge, 2007.

[2] P. M. Chapman, "Global Climate Change Means Never Going Home Again," Marine Pollution Bulletin, Vol. 62, No. 11, 2011, pp. 2269-2270. doi:10.1016/j.marpolbul.2011.08.031

[3] X. Durrieu de Madron, C. Guieu, R. Sempéré, P. Conan, D. Cossa, F. d'Ortenzio, C. Estournel, F. Gazeau, C. Rabouille, L. Stemmann, S. Bonnet, F. Diaz, P. Koubbi, O. Radakovitch, M. Babin, M. Baklouti, C. BanconMontigni, S. Belviso, N. Bensoussan, B. Bonsang, I. Bouloubassi, C. Brunet, J.-F. Cadiou, F. Carlotti, M. Chami, S. Charmasson, B. Charrière, J. Dachs, D. Doxaran, J.-C. Dutay, F. Elbaz-Poulichet, M. Eléaume, F. Eyrolles, C. Fernandez, S. Fowler, P. Francour, J. C. Gaertner, R. Galzin, S. Gasparini, J.-F. Ghiglione, J.-L. Gonzalez, C. Goyet, L. Guidi, K. Guizien, L.-E. Heimbürger, S. H. M. Jacquet, W. H. Jeffrey, F. Joux, P. Le Hir, K. Leblanc, D. Lefèvre, C. Lejeusne, R. Lemé, M.-D. Loÿe-Pilot, M. Mallet, L. Méjanelle, F. Mélin, C. Mellon, B. Mérigot, P.-L. Merle, C. Migon, W. L. Miller, L. Mortier, B. Mostajir, L. Mousseau, T. Moutin, J. Para, T. Pérez, A. Petrenko, J.-C. Poggiale, L. Prieur, M. Pujo-Pay, PulidoVillena, P. Raimbault, A. P. Rees, C. Ridame, J.-F. Rontani, D. Ruiz Pino, M. A. Sicre, V. Taillandier, C. Tamburini, T. Tanaka, I. Taupier-Letage, M. Tedetti, P. Testor,
H. Thébault, B. Thouvenin, F. Touratier, J. Tronczynski, C. Ulses, F. Van Wambeke, V. Vantrepotte, S. Vaz and R. Verney, "Marine Ecosystems' Responses to Climatic and Anthropogenic Forcings in the Mediterranean," Progress in Oceanography, Vol. 91, No. 2, 2011, pp. 97-166. doi:10.1016/i.pocean.2011.02.003

[4] C. J. M. Philippart, R. Anadón, R. Danovaro, J. W. Dippner, K. F. Drinkwater, S. J. Hawkins, T. Oguz, G. O'Sullivan and P. C. Reid, "Impacts of Climate Change on European Marine Ecosystems: Observations, Expectations and Indicators," Journal of Experimental Marine Biology and Ecology, Vol. 400, No. 1-2, 2011, pp. 52-69. doi:10.1016/j.jembe.2011.02.023

[5] B. S. Halpern, S. Walbridge, K. A. Selkoe, C. V. Kappel, F. Micheli, C. D’Agrosa, J. F. Bruno, K. S. Casey, C. Ebert, H. E. Fox, R. Fujita, D. Heinemann, H. S. Lenihan, E. M. P. Madin, M. T. Perry, E. R. Selig, M. Spalding, R. Steneck and R. Watson, "A Global Map of Human Impact on Marine Ecosystems," Science, Vol. 319, No. 5865, 2008, pp. 948-952. doi:10.1126/science.1149345

[6] I. Rombouts, G. Beaugrand, L. F. Artigas, J.-C. Dauvin, F. Gevaert, E. Goberville, D. Kopp, S. Lefebvre, C. Luczak, N. Spilmont, M. Travers-Trolet, C. M. Villanueva and R. R. Kirby, "Tools to Derive Indicators of Marine Ecosystem Structure and Functioning: Case Studies Using Direct Observations and Modelling Methods," Ecological Indicators, Vol. 24, 2013, pp. 353-365. doi:10.1016/j.ecolind.2012.07.001

[7] S. Bevilacqua, S. Fraschetti, L. Musco, G. Guarnieri and A. Terlizzi, "Low Sensitiveness of Taxonomic Distinctness Indices to Human Impacts: Evidences Across Marine Benthic Organisms and Habitat Types," Ecological Indicators, Vol. 11, No. 2, 2011, pp. 448-455.

doi:10.1016/j.ecolind.2010.06.016

[8] R. J. Diaz, M. Solan and R. M. Valente, "A Review of Approaches for Classifying Benthic Habitats and Evaluating Habitat Quality," Journal of Environmental Management, Vol. 73, No. 3, 2004, pp. 165-181. doi:10.1016/j.jenvman.2004.06.004

[9] S. Birk, W. Bonne, A. Borja, S. Brucet, A. Courrat, S. Poikane, A. Solimini, W. van de Bund, N. Zampoukas and D. Hering, "Three Hundred Ways to Assess Europe's Surface Waters: An Almost Complete Overview of Biological Methods to Implement the Water Framework Directive," Ecological Indicators, Vol. 18, No. 1, 2012, pp. 31-41. doi:10.1016/j.ecolind.2011.10.009

[10] G. Van Hoey, A. Borja, S. Birchenough, L. Buhl-Mortensen, S. Degreaer, D. Fleisher, F. Kerckhof, P. Magni, I. Muxika, H. Reiss, A. Schröder and M. Zettler, "The Use of Benthic Indicators in Europe: From the Water Framework Directive to the Marine Strategy Framework Directive," Marine Pollution Bulletin, Vol. 60, No. 12, 2010, pp. 2187-2196. doi:10.1016/j.marpolbul.2010.09.015

[11] D. A. Smale, T. J. Langlois, G. A. Kendrick, J. J. Meeuwig and E. S. Harvey, "From Fronds to Fish: The Use of Indicators for Ecological Monitoring in Marine Benthic Ecosystems, with Case Studies from Temperate Western Australia," Reviews in Fish Biology and Fisheries, Vol. 21, No. 3, 2011, pp. 311-337. doi:10.1007/s11160-010-9173-7 
[12] J.-C. Dauvin, S. Alizier, C. Rolet, A. Bakalem, G. Bellan, J. L. Gomez Gesteira, S. Grimes, J. A. de-la-Ossa-Carretero and Y. Del-Pilar-Ruso, "Response of Different Benthic Indices to Diverse Human Pressures," Ecological Indicators, Vol. 12, No. 1, 2012, pp. 143-153. doi:10.1016/j.ecolind.2011.03.019

[13] J.-C. Dauvin, G. Bellan and D. Bellan-Santini, "Benthic Indicators: From Subjectivity to Objectivity-Where Is the Line?" Marine Pollution Bulletin, Vol. 60, No. 7, 2010, pp. 947-953. doi:10.1016/j.marpolbul.2010.03.028

[14] U. Heink and I. Kowarik, "What Are Indicators? On the Definition of Indicators in Ecology and Environmental Planning," Ecological Indicators, Vol. 10, No. 3, 2010, pp. 584-593. doi:10.1016/j.ecolind.2009.09.009

[15] A. Borja, J. Franco and V. Perez, "A Marine Biotic Index to Establish the Ecological Quality of Soft-Bottom Benthos within European Estuarine and Coastal Environments," Marine Pollution Bulletin, Vol. 40, No. 12, 2000, 1100-1114. doi:10.1016/S0025-326X(00)00061-8

[16] R. M. Warwick, "The Level of Taxonomic Discrimination Required to Detect Pollution Effects on Marine Benthic Communities," Marine Pollution Bulletin, Vol. 19, No. 6, 1988, pp. 259-268. doi:10.1016/0025-326X(88)90596-6

[17] A. Borja and D. M. Dauer, "Assessing the Environmental Quality Status in Estuarine and Coastal Systems: Comparing Methodologies and Indices," Ecological Indicators, Vol. 8, No. 4, 2008, pp. 331-337. doi:10.1016/j.ecolind.2007.05.004

[18] I. Muxika, A. Borja and W. Bonne, "The Suitability of the Marine Biotic Index (AMBI) to New Impact Sources Along European Coasts," Ecological Indicators, Vol. 5, No. 1, 2005, pp. 19-31. doi:10.1016/j.ecolind.2004.08.004

[19] F. Salas, J. M. Neto, A. Borja and J. C. Marques, "Evaluation of the Applicability of a Marine Biotic Index to Characterize the Status of Estuarine Ecosystems: The Case of Mondego Estuary (Portugal)," Ecological Indicators, Vol. 4, No. 3, 2004, pp. 215-225. doi:10.1016/j.ecolind.2004.04.003

[20] R. Pinto, J. Patricio, A. Baeta, B. D. Fath, J. M. Neto and J. C. Marques, "Review and Evaluation of Estuarine Biotic Indices to Assess Benthic Condition," Ecological Indicators, Vol. 9, No. 1, 2009, pp. 1-25. doi:10.1016/j.ecolind.2008.01.005

[21] M. Mabe and M. Amin, "Growth Dynamics of Scholarly and Scientific Journals," Scientometrics, Vol. 51, No. 1, 2001, pp. 147-162. doi:10.1023/A:1010520913124

[22] P. O. Larsen and M. von Is, "The Rate of Growth in Scientific Publication and the Decline in Coverage Provided by Science Citation Index," Scientometrics, Vol. 84, No. 3, 2010, pp. 575-603. doi:10.1007/s11192-010-0202-Z

[23] M. W. Neff and E. A. Corley, "35 Years and 160,000 Articles: A Bibliometric Exploration of the Evolution of Ecology," Scientometrics, Vol. 80, No. 3, 2009, pp. 657-682. doi:10.1007/s11192-008-2099-3

[24] J.-P. Gattuso, N. A. Dawson, C. M. Duarte and J. J. Middelburg, "Patterns of Publication Effort in Coastal Biogeochemistry: A Bibliometric Survey (1971 to 2003),"
Marine Ecology Progress Series, Vol. 294, 2005, pp. 922. doi:10.3354/meps294009

[25] J. Sun, M. H. Wang and Y.-S. Ho, "A Historical Review and Bibliometric Analysis of Research on Estuary Pollution," Marine Pollution Bulletin, Vol. 64, No. 1, 2012, pp. 13-21. doi:10.1016/j.marpolbul.2011.10.034

[26] H. Yi and W. Jie, "A Bibliometric Study of the Trend in Articles Related to Eutrophication Published in Science Citation Index," Scientometrics, Vol. 89, No. 3, 2011, pp. 919-927. doi:10.1007/s11192-011-0479-6

[27] F. Ibanez, J.-M. Fromentin and J. Castel, “Application of the Cumulated Function to the Processing of Chronological Data in Oceanography," Comptes Rendus de l'Académie des Sciences Série III-Sciences de la Vie-Life Sciences, Vol. 316, 1993, pp. 745-748.

[28] I. Karakassis, P. D. Dimitriou, N. Papageorgiou, E. T. Apostolaki, N. Lampadariou and K. D. Black, "Methodological Considerations on the Coastal and Transitional Benthic Indicators Proposed for the Water Framework Directive," Ecological Indicators, Vol. 29, 2013, pp. 2633. doi:10.1016/j.ecolind.2012.12.020

[29] T. Bacci, B. Trabucco, S. Marzialetti, V. Marusso, S. Lomiri, D. Vani and C. V. Lamberti, "Taxonomic Sufficiency in Two Case Studies: Where Does It Work Better?" Marine Ecology, Vol. 30, No. Suppl. 1, 2009, pp. 13-19. doi:10.1111/j.1439-0485.2009.00324.x

[30] J. A. de-la-Ossa-Carretero, N. Simboura, Y. Del-PilarRuso, M. A. Pancucci-Papadopoulou, F. Giménez-Casualduero and J. L. Sánchez-Lizaso, "A Methodology for Applying Taxonomic Sufficiency and Benthic Indices in Two Mediterranean Areas," Ecological Indicators, Vol. 23, 2012, pp. 232-241. doi:10.1016/j.ecolind.2012.03.029

[31] H. Teixeira, A. Borja, S. B. Weisberg, J. A. Ranasinghe, D. B. Cadien, D. M. Dauer, J.-C. Dauvin, S. Degraer, R. J. Diaz, A. Grémare, I. Karakassis, R. J. Llansó, L. L. Lovell, J. C. Marques, D. E. Montagne, A. Occhipinti-Ambrogi, R. Rosenberg, R. Sardá, L. C. Schaffner and R. G. Velarde, "Assessing Coastal Benthic Macrofauna Community Condition Using Best Professional JudgementDe-veloping Consensus Across North America and Europe," Marine Pollution Bulletin, Vol. 60, No. 4, 2010, pp. 589-600. doi:10.1016/j.marpolbul.2009.11.005

[32] A. Afli, R. Ayari and S. Zaabi, "Ecological Quality of Some Tunisian Coast and Lagoon Locations, by Using Benthic Community Parameters and Biotic Indices," Estuarine, Coastal and Shelf Science, Vol. 80, No. 2, 2008, pp. 269-280. doi:10.1016/j.ecss.2008.08.010

[33] H. Blanchet, N. Lavesque, T. Ruellet, J.-C. Dauvin, P.-G. Sauriau, N. Desroy, C. Desclaux, M. Leconte, G. Bachelet, A.-L. Janson, C. Bessineton, S. Duhamel, J. Jourde, S. Mayot, S. Simon and X. de Montaudouin, "Use of Biotic Indices in Semi-Enclosed Coastal Ecosystems and Transitional Waters Habitats-Implications for the Implementation of the European Water Framework Directive," Ecological Indicators, Vol. 8, No. 4, 2008, pp. 360-372. doi:10.1016/j.ecolind.2007.04.003

[34] A. Borja, D. M. Dauer, R. Díaz, R. J. Llansó, I. Muxika, J. G. Rodríguez and L. Schaffner, "Assessing Estuarine Benthic Quality Conditions in Chesapeake Bay: A Com- 
parison of Three Indices," Ecological Indicators, Vol. 8, No. 4, 2008, pp. 395-403.

doi:10.1016/i.ecolind.2007.05.003

[35] A. Borja, J. G. Rodríguez, K. Black, A. Bodoy, C. Emblow, T. F. Fernandes, J. Forte, I. Karakassis, I. Muxika, T. D. Nickell, N. Papageorgiou, F. Pravoni, K. Sevastou, P. Tomassetti and D. Angel, "Assessing the Suitability of a Range of Benthic Indices in the Evaluation of Environmental Impact of Fin and Shellfish Aquaculture Located in Sites Across Europe," Aquaculture, Vol. 293, No. 3-4, 2009, pp. 231-240.

doi:10.1016/j.aquaculture.2009.04.037

[36] N. Lavesque, H. Blanchet and X. de Montaudouin, "Development of a Multimetric Approach to Assess Perturbation of Benthic Macrofauna in Zostera noltii Beds," Journal of Experimental Marine Biology and Ecology, Vol. 368, No. 2, 2009, pp. 101-112. doi:10.1016/j.jembe.2008.09.017

[37] R. Simonini, V. Grandi, G. Massamba-N'Siala, M. Lotti, G. Montarani and D. Prevedelli, "Assessing the Ecological Status of North-Western Adriatic Sea within the European Framework Directive: A Comparison of Bentix, AMBI and M-AMBI Methods," Marine Ecology, Vol. 30, No. 2, 2009, pp. 241-254. doi:10.1111/j.1439-0485.2009.00281.x

[38] S. J. Ware, H. L. Rees, S. E. Boyd and S. N. Birchenhough, "Performance of Selected Indicators in Evaluating the Consequences of Dredged Material Relocation and Marine Aggregate Extraction," Ecological Indicators, Vol. 9, No. 4, 2009, pp. 704-718.

doi:10.1016/j.ecolind.2008.09.010

[39] S. Grimes, T. Ruellet, J.-C. Dauvin and Z. Boutida, "Ecological Quality Status of the Soft-Bottom Communities on the Algerian Coast: General Patterns and Diagnosis," Marine Pollution Bulletin, Vol. 60, No. 11, 2010, pp. 1969-1977. doi:10.1016/j.marpolbul.2010.07.032

[40] A. Borja, E. Barbone, A. Basset, G. Borgensen, M. Brkljacic, M. Elliott, J. M. Garmendia, J. C. Marques, K. Mazik, I. Muxika, J. M. Neto, K. Norling, J. G. Rodríguez, I. Rosati, B. Rygg, H. Teixeira and A. Trayanova, "Response of Single Benthic Metrics and MultiMetric Methods to Anthropogenic Pressure Gradients, in Five Distinct European Coastal and Transitional Ecosystems," Marine Pollution Bulletin, Vol. 62, No. 3, 2011, pp. 499-513. doi:10.1016/j.marpolbul.2010.12.009

[41] C. Murani and M. Mistri, "Ecological Status Assessment and Response of Benthic Communities to Environmental Variability: The Valli di Comacchio (Italy) as a Case Study," Marine Environmental Research, Vol. 81, 2012, pp. 53-61. doi:10.1016/j.marenvres.2012.08.008

[42] F. Salas, C. Marcos, J. M. Neto, J. Patrício, A. PérezRuzafa and J. C. Marques, "User-Friendly Guide for Using Benthic Ecological Indicators in Coastal and Marine Quality assessment," Ocean and Coastal Management, Vol. 49, No. 5-6, 2006, pp. 308-331.

doi:10.1016/j.ocecoaman.2006.03.001

[43] H. Reiss and I. Kröncke, "Seasonal Variability of Benthic Indices: An Approach to Test the Applicability of Different Indices for Ecosystem Quality Assessment," Marine Pollution Bulletin, Vol. 50, No. 12, 2005, pp. 1490-1499. doi:10.1016/j.marpolbul.2005.06.017

[44] J.-C. Dauvin, G. Bachelet, A.-L. Barillé, H. Blanchet, X. de Montaudouin, N. Lavesque and T. Ruellet, "Benthic Indicators and Index Approaches in the Three Main Estuaries along the French Atlantic Coast (Seine, Loire and Gironde)," Marine Ecology, Vol. 30, No. 2, 2009, pp. 228-240. doi:10.1111/j.1439-0485.2008.00274.x

[45] I. Kröncke and H. Reiss, "Influence of Macro-Fauna Long-Term Natural Variability on Benthic Indices Used in Ecological Quality Assessment," Marine Pollution Bulletin, Vol. 60, No. 1, 2010, pp. 58-68. doi:10.1016/j.marpolbul.2009.09.001

[46] J. E. Fitch and T. P. Crowe, "Effective Methods for Assessing Ecological Quality in Intertidal Soft-Sediment Habitats," Marine Pollution Bulletin, Vol. 60, No. 10, 2010, pp. 1726-1733. doi:10.1016/j.marpolbul.2010.06.027

[47] E. Quiroga, P. Ortiz, B. Reid and D. Gerdes, "Classification of the Ecological Quality of the Aysen and Bker Fjords (Patagonia, Chile) Using Biotic Indices," Marine Pollution Bulletin, Vol. 68, No. 1-2, 2013, pp. 117-126. doi:10.1016/j.marpolbul.2012.11.041

[48] J. A. de-la-Ossa-Carretero, Y. del-Pilar-Ruso, F. Giménez-Casalduero and J. L. Sánchez-Lizaso, "Testing BOPA Index in Seawage Affected Soft-Bottom Communities in the North-Western Mediterranean," Marine Pollution Bulletin, Vol. 58, No. 3, 2009, 332-340. doi:10.1016/j.marpolbul.2008.10.017

[49] R. Bermejo, J. J. Vergaga and I. Hernández, “Application and Reassessment of the Reduces Species List Index for Macroalgae to Assess the Ecological Status under the Water Framework Directive in the Atlantic Coast of Southern Spain," Ecological Indicators, Vol. 12, No. 1, 2012, pp. 46-57. doi:10.1016/j.ecolind.2011.04.008

[50] J.-C. Dauvin and T. Ruellet, "Polychaete/Amphipod Ratio Revisited," Marine Pollution Bulletin, Vol. 55, No. 1-6, 2007, pp. 215-224.

[51] J.-C. Dauvin and T. Ruellet, "The Estuarine Quality Paradox: Is It Possible to Define an Ecological Quality Status for Specific Modified and Naturally Stressed Estuarine Ecosystems?" Marine Pollution Bulletin, Vol. 59, No. 1-3, 2009, pp. 38-47.

doi:10.1016/j.marpolbul.2008.11.008

[52] R. Gaspar, L. Pereira and J. M. Neto, "Ecological Reference Conditions and Quality States of Marine Macroalgae sensu Water Framework Directive: An Example from the Intertidal Rocky Shores of the Portuguese Coastal Waters," Ecological Indicators, Vol. 19, 2012, pp. 24-38. doi:10.1016/j.ecolind.2011.08.022

[53] J. M. Neto, R. Gaspar, L. Pereira and J. C. Marques, "Marine Macroalgae Assessment Tool (MarMAT) for Intertidal Rocky Shores. Quality Assessment under the Scope of the European Water Framework Directive," Ecological Indicators, Vol. 19, 2012, pp. 39-47. doi:10.1016/j.ecolind.2011.09.006

[54] I. Díez, M. Bustamante, A. Santolaria, J. Tajadura, N. Muguerza, A. Borja, I. Muxika, J. I. Saiz-Salinas and J. M. Gorostiaga, "Development of a Tool for Assessing the Ecological Quality Status of Intertidal Coastal Rocky 
Assemblages, within Atlantic Iberian Coasts," Ecological Indicators, Vol. 12, No. 1, 2011, 58-71. doi:10.1016/j.ecolind.2011.05.014

[55] A. S. Alves, H. Adão, T. J. Ferrero, J. C. Marques, M. J. Costa and J. Patrício, "Benthic Meiofauna as Indicator of Ecological Changes in Estuarine Ecosystems: The Use of Nematodes in Ecological Quality Assessment," Ecological Indicators, Vol. 24, 2013, pp. 462-475. doi:10.1016/j.ecolind.2012.07.013

[56] V. M. P. Bouchet, E. Alve, B. Rygg and R. J. Telford, "Benthic Foraminifera Provide a Promising Tool for Ecological Quality Assessment of Marine Waters," Ecological Indicators, Vol. 23, 2012, pp. 66-75. doi:10.1016/j.ecolind.2012.03.011

[57] S. Donnici, R. Serandrei-Barbero, M. Bonardi and M. Sperle, "Benthic Foraminifera as Proxies of Pollution: The Case of Guanabara Bay (Brazil)," Marine Pollution Bulletin, Vol. 64, No. 10, 2012, 2015-2028. doi:10.1016/j.marpolbul.2012.06.024

[58] M. Balsamo, F. Semprucci, F. Frontalini and R. Coccioni, "Meiofauna as a Tool for Marine Ecosystem Biomonitoring," In: A. Cruzado, Ed., Marine Ecosystems, InTech, Rijeka, 2012, pp. 77-104. doi:10.5772/34423

[59] M. Elliott, "Marine Science and Management Means Tackling Exogenic Unmanaged Pressures and Endogenic Managed Pressures-A Numbered Guide," Marine Pollution Bulletin, Vol. 62, No. 4, 2011, pp. 651-655. doi:10.1016/j.marpolbul.2010.11.033

[60] B. Beliaeff and D. Pelletier, "A General Framework for Indicator Design and Use with Application to the Assessment of Coastal Water Quality and Marine Protected Area Management," Ocean and Coastal Management, Vol. 54, No. 1, 2011, pp. 84-92. doi:10.1016/j.ocecoaman.2010.10.037

[61] E. Goberville, G. Beaugrand, B. Sautour and P. Tréguer, "Evaluation of Coastal Perturbations: A New Mathematical Procedure to Detect Changes in the Reference State of Coastal Systems," Ecological Indicators, Vol. 11, No. 5, 2011, pp. 1290-1300. doi:10.1016/j.ecolind.2011.02.002

[62] C. Luczak and N. Spilmont, "Are the Eastern and Western Basins of the English Channel Two Separate Ecosystems? Get Back in Line with Some Cautionary Comments," Marine Pollution Bulletin, Vol. 64, No. 7, 2012, pp. 1318-1319. doi:10.1016/j.marpolbul.2012.05.006

[63] J.-C. Dauvin, "Response by Dauvin to correspondence by Christophe Luczak and Nicolas Spilmont on 'Are the Eastern and Western Basins of the English Channel Two Separate Ecosystems? Get back in Line with Some Cautionary comments'," Marine Pollution Bulletin, Vol. 64, No. 11, 2012, 2615-2616. doi:10.1016/j.marpolbul.2012.07.004

[64] G. Allison, "The Influence of Species Diversity and Stress Intensity on Community Resistance and Resilience," Ecological Monographs, Vol. 74, 2004, pp. 117134. doi:10.1890/02-0681

[65] J. Hellou, "Behavioural Ecotoxicology, an 'Early Warning' Signal to Assess Environmental Quality," Environmental Science and Pollution Research, Vol. 18, No. 1, 2011, pp. 1-11. doi:10.1007/s11356-010-0367-2
[66] B. Helmuth, C. D. G. Harley, P. M. Halpin, M. O'Donnell, G. E. Hofmann and C. A. Blanchette, "Climate Change and Latitudinal Patterns of Intertidal Thermal Stress," Science, Vol. 298, No. 5595, 2002, pp. 10151017. doi:10.1126/science.1076814

[67] C. D. G. Harley, "Climate Change, Keystone Predation, and Biodiversity Loss," Science, Vol. 334, No. 6059, 2011, pp. 1124-1127. doi:10.1126/science.1210199

[68] D. Madeira, L. Narciso, H. N. Cabral and C. Vinagre, "Thermal Tolerance and Potential Impacts of Climate Change on Coastal and Estuarine Organisms," Journal of Sea Research, Vol. 70, 2012, pp. 32-41. doi:10.1016/j.seares.2012.03.002

[69] D. Raffaelli and S. Hawkins, "Intertidal Ecology," Chapman \& Hall, London, 1996. doi:10.1007/978-94-009-1489-6

[70] W. Klaassen and N. Spilmont, "Inter-Annual Variability of $\mathrm{CO}_{2}$ Exchanges between an Emersed Tidal Flat and the Atmosphere," Estuarine, Coastal and Shelf Science, Vol. 100, 2012, pp. 18-25. doi:10.1016/j.ecss.2011.06.002

[71] H. Thomas, Y. Bozec, K. Elkalay and H. J. M. de Baar, "Enhanced Open Ocean Storage of $\mathrm{CO}_{2}$ from Shelf Sea Pumping," Science, Vol. 304, No. 5673, 2004, pp. 1005 1008. doi:10.1126/science.1095491

[72] F. E. Muller-Karger, R. Varela, R. Thunell, R. Luerssen and J. J. Walsh, "The Importance of Continental Margins in the Global Carbon Cycle," Geophysical Research Letters, Vol. 32, No. 1, 2005, Article ID: L01602. doi:10.1029/2004GL021346

[73] J. H. Connell, "The Influence of Intra-Specific Competition and Other Factors on the Distribution of the Barnacle Chthamalus stellatus," Ecology, Vol. 42, No. 4, 1961, 710-723. doi: $10.2307 / 1933500$

[74] R. T. Paine, "The Pisaster-Tegula Interaction: Prey Patches, Predator Food Preferences and Intertidal Community Structure," Ecology, Vol. 50, No. 6, 1969, pp. 950-961. doi: $10.2307 / 1936888$

[75] A. J. Underwood, "Comparative Studies on the Biology of Nerita atramentosa Reeve, Benbicium nancum (Lamarck) and Cellana tramoserica (Sowerby) (Gastropoda: Prosobranchia) in S.E. Australia," Journal of Experimental Marine Biology and Ecology, Vol. 18, No. 2, 1975, pp. 153-172. doi:10.1016/0022-0981(75)90071-4

[76] F. Colijn, "Light Absorption in the Waters of the EmsDollard Estuary and its Consequences for the Growth of Phytoplankton and Microphytobenthos," Netherlands Journal of Sea Research, Vol. 15, No. 2, 1982, 196-216. doi:10.1016/0077-7579(82)90004-7

[77] G. C. Jensen, P. S. McDonald and D. A. Armstrong, "East Meets West: Competitive Interactions between Green Crab Carcinus maenas, and Native and Introduced Shore Crab Hemigrapsus spp," Marine Ecology Progress Series, Vol. 225, 2002, pp. 251-262. doi:10.3354/meps225251

[78] W. L. Whitlow, "Changes in Survivorship, Behavior, and Morphology in Native Soft-Shell clams Induced by Invasive Green Crab Predators," Marine Ecology, Vol. 31, No. 3, 2010, pp. 418-430.

[79] A. C. Jackson and J. McIlvenny, "Coastal Squeeze on 
Rocky Shores in Northern Scotland and Some Possible Ecological Impacts," Journal of Experimental Marine Biology and Ecology, Vol. 400, No. 1-2, 2011, pp. 314-321. doi:10.1016/i.jembe.2011.02.012

[80] A. B. Aloy, B. M. Vallelo, Jr and M. A. Juinio-Meñez, "Increased Plastic Litter Cover Affects the Foraging Activity of the Sandy Intertidal Gastropod Nassarius pullus," Marine Pollution Bulletin, Vol. 62, No. 8, 2011, pp. 1772-1779. doi:10.1016/j.marpolbul.2011.05.021

[81] C. V. M. Araújo, J. Blasco and I. Moreno-Garrido, "Measuring the Avoidance Behaviour Shown by the Snail $\mathrm{Hy}$ drobia ulvae Exposed to Sediment with a Known Contamination Gradient," Ecotoxicology, Vol. 21, No. 3, 2012, pp. 750-758. doi:10.1007/s10646-011-0835-6

[82] J. D. Nuez, M. V. Laitano and M. Cledón, “An Intertidal Limpet Species as a Bioindicator: Pollution Effects Reflected by Shell Characteristics," Ecological Indicators, Vol. 14, No. 1, 2012, pp. 178-183. doi:10.1016/j.ecolind.2011.07.015

[83] B. Manachini, V. Arizza, A. Rinaldi, V. Montalto and G. Sarà, "Eco-Physiological Response of Two Marine Bivalves to Acute Exposition to Commercial Bt-Based Pesticide," Marine Environmental Research, Vol. 83, 2013, pp. 29-37. doi:10.1016/j.marenvres.2012.10.006

[84] S. Melatunan, P. Calosi, S. D. Rundle, A. J. Moody and S. Widdicombe, "Exposure to Elevated Temperature and $\mathrm{P}_{\mathrm{CO} 2}$ Reduces Respiration Rate and Energy Status in the Periwinkle Littorina littorea," Physiological and Biochemical Zoology, Vol. 84, No. 6, 2011, pp. 583-594. doi: $10.1086 / 662680$

[85] K. L. de la Haye, J. I. Spicer, S. Widdicombe and M. Briffa, "Reduced pH Sea Water Disrupt Chemo-Responsive Behaviour in an Intertidal Crustacean," Journal of Experimental Marine Biology and Ecology, Vol. 412, 2012, pp. 134-140. doi:10.1016/j.jembe.2011.11.013

[86] C. Chapperon and L. Seuront "Behavioral Thermoregulation in a Tropical Gastropod: Links to Climate Change Scenarios," Global Change Biology, Vol. 17, No. 4, 2011, pp. 1740-1749. doi:10.1111/j.1365-2486.2010.02356.x

[87] S. R. Cartwright and C. A. Williams, "Seasonal Variation in Utilization of Biogenic Microhabitats by Littorinid Snails on Tropical Rocky Shores," Marine Biology, Vol. 159, No. 10, 2012, pp. 2323-2332. doi:10.1007/s00227-012-2017-3

[88] E. K. Fly, C. J. Monaco, S. Pincebourde and A. Tullis, "The Influence of Intertidal Location and Temperature on the Metabolic Coast of Emersion in Pisaster ochraceus," Journal of Experimental Marine Biology and Ecology, Vol. 422-423, 2012, pp. 20-28. doi:10.1016/i.jembe.2012.04.007

[89] S. G. Cheung, H. Y. Wai and P. K. S. Shin, "Fatty Acid Profiles of Benthic Environment Associated with Artificial Reefs in Subtropical Hong Kong," Marine Pollution Bulletin, Vol. 60, No. 2, 2010, 303-308. doi:10.1016/j.marpolbul.2009.12.001

[90] K. Grangeré, S. Lefebvre and J. L. Blin, "Spatial and Temporal Dynamics of Biotic and Abiotic Features of Temperate Coastal Ecosystems as Revealed by a Combination of Ecological Indicators," Estuarine, Coastal and
Shelf Science, Vol. 108, 2012, pp. 109-118. doi:10.1016/j.ecss.2012.02.020

[91] N. G. Barr, B. D. Dudley, K. M. Rogers and C. D. Cornelisen, "Broad-Scale Patterns of Tissue- $\delta^{15} \mathrm{~N}$ and Tissue-N Indices in Frondose Ulva spp.; Developing a National Baseline Indicator of Nitrogen-Loading for Coastal New Zealand," Marine Pollution Bulletin, Vol. 67, No. 1-3, 2013, pp. 203-216. doi:10.1016/j.marpolbul.2012.11.033

[92] N. Spilmont, A. Migné, L. Seuront and D. Davoult, "Short-Term Variability of Intertidal Benthic Community Production during Emersion and the Implication in Annual Budget Calculation," Marine Ecology Progress Series, Vol. 333, 2007, pp. 95-101. doi:10.3354/meps333095

[93] A. Migné, N. Spilmont, G. Boucher, L. Denis, C. Hubas, M.-A. Janquin, M. Rauch and D. Davoult, "Annual Budget of Benthic Production in Mont Saint-Michel Bay Considering Cloudiness, Microphytobenthos Migration, and Variability of Respiration Rates With Tidal Conditions," Continental Shelf Research, Vol. 29, No. 19, 2009, pp. 2280-2285. doi:10.1016/j.csr.2009.09.004

[94] N. Spilmont, A. Migné, A. Lefebvre, L. F. Artigas, M. Rauch and D. Davoult, "Temporal Variability of Intertidal Benthic Metabolism under Emersed Conditions in an exposed Sandy Beach (Wimereux, Eastern English Channel, France)," Journal of Sea Research, Vol. 53, No. 3, 2005, pp. 161-167. doi:10.1016/j.seares.2004.07.004

[95] C. Hubas and D. Davoult, "Does Seasonal Proliferation of Enteromorpha sp. Affect the Annual Benthic Metabolism of a Small Macrotidal Estuary? (Roscoff Aber Bay, France)," Estuarine, Coastal and Shelf Science, Vol. 70, No. 1-2, 2006, pp. 287-296. doi:10.1016/j.ecss.2006.06.019

[96] N. Spilmont, L. Denis, L. F. Artigas, F. Caloin, L. Courcot, A. Créach, N. Desroy, F. Gevaert, P. Hacquebart, C. Hubas, M.-A. Janquin, Y. Lemoine, C. Luczak, A. Migné, M. Rauch and D. Davoult, "Impact of the Phaeocystis globosa Spring Bloom on the Intertidal Benthic Compartment in the Eastern English Channel: A Synthesis," Marine Pollution Bulletin, Vol. 58, No. 1, 2009, pp. 5563. doi:10.1016/j.marpolbul.2008.09.007

[97] A. Migné, V. Ouisse, C. Hubas and D. Davoult, "Freshwater Seepages and Ephemeral Macroalgae Proliferation in an Intertidal Bay: II. Effect on Benthic Biomass and Metabolism," Estuarine, Coastal and Shelf Science, Vol. 92, No. 1, 2012, pp. 161-168. doi:10.1016/j.ecss.2010.12.023

[98] N. Valvidia, C. Golléty, A. Migné, D. Davoult and M. Molis, "Stressed but Stable: Canopy Loss Decreased Species Synchrony and Metabolic Variability in an Intertidal Hard-Bottom Community," PloS One, Vol. 7, No. 5, 2012, Article ID: e36541. doi:10.1371/journal.pone.0036541

[99] C. Golléty, D. Davoult and F. Gentil, "Secondary Production, Calcification and $\mathrm{CO}_{2}$ Fluxes in the Cirripedes Chtalamus montagui and Elminius modestus," Oecologia, Vol. 155, No. 1, 2008, pp. 133-142. doi:10.1007/s00442-007-0895-8

[100] R. C. Thompson, T. P. Crowe and S. J. Hawkins, "Rocky 
Intertidal Communities: Past Environmental Changes, Present Status and Predictions for the Next 25 Years," Environmental Conservation, Vol. 29, No. 2, 2002, pp. 168-191. doi:10.1017/S0376892902000115

[101] J. E. Fitch and T. P. Crowe, "Combined Effects of Temperature, Inorganic Nutrients and Organic Matter on Ecosystem Processes in Intertidal Sediments," Journal of Experimental Marine Biology and Ecology, Vol. 400, No. 1-2, 2011, pp. 257-263. doi:10.1016/j.jembe.2011.02.005

[102] S. Pincebourde, E. Sanford, J. Casas and B. Helmuth, "Temporal Coincidence of Environmental Stress Events Modulates Predation Rates," Ecology Letters, Vol. 15, No. 7, 2012, pp. 680-688. doi:10.1111/j.1461-0248.2012.01785.x

[103] T. Meziane, L. Bodineau, C. Retiere, and G. Thoumelin, "The Use of Lipid Markers to Define Sources of Organic Matter in Sediment and Food Web of the Intertidal Salt-Marsh-Flat Ecosystem of the Mont-Saint-Michel Bay, France," Journal of Sea Research, Vol. 38, No. 1-2, 1997, pp. 47-58. doi:10.1016/S1385-1101(97)00035-X

[104] J. R. Kelly and R. E. Scheibling, "Fatty Acids as Dietary Tracers in Benthic Food Webs," Marine Ecology Progress Series, Vol. 446, 2012, pp. 1-22. doi:10.3354/meps09559
[105] D. D. Baldocchi, “Assessing the Eddy Covariance Technique for Evaluating Carbon Dioxide Exchange Rates in Ecosystems: Past, Present and Future," Global Change Biology, Vol. 9, No. 4, 2003, pp. 479-492. doi:10.1046/j.1365-2486.2003.00629.x

[106] P. Polsenaere, E. Lamaud, V. Lafon, J.-M. Bonnefond, P. Bretel, B. Delille, J. Deborde, D. Loustau and G. Abril, "Spatial and Temporal $\mathrm{CO}_{2}$ Exchanges Measured by Eddy Correlation over a Temperate Intertidal Flat and Their Relationships to Net Ecosystem Production," Biogeosciences, Vol. 9, 2012, pp. 249-268. doi:10.5194/bg-9-249-2012

[107] J. P. Cohn, "Citizen Science: Can Volunteers do Real Research?” BioScience, Vol. 58, No. 3, 2008, pp. 192-197. doi:10.1641/B580303

[108] J. Silvertown, "A New Dawn for Citizen Science," Trends in Ecology and Evolution, Vol. 24, No. 9, 2009, pp. 467-471. doi:10.1016/j.tree.2009.03.017

[109] D. G. Delaney, C. D. Sperling, C. S. Adams and B. Leung, "Marine Invasive Species: Validation of Citizen Science and Implications for National Monitoring Networks," Biological Invasions, Vol. 10, No. 1, 2008, pp. 117-128. doi:10.1007/s10530-007-9114-0 